\title{
Localization of Hyaluronidase in the Urogenital Organs of Sheep, Revealed by Fluorescent Antibody Method
}

By

\author{
Ichiro Nagakubo*, Kunio Takano** and Kenjiro Yasuda** \\ Department of Urology* and Department of Anatomy**, School of \\ Medicine, Keio University, Shinjuku, Tokyo, Japan
}

\section{Introduction}

In $1928, \mathrm{D}$ u r a $\mathrm{n}-\mathrm{R}$ e y $\mathrm{n}$ a $\mathrm{l} \mathrm{s}$ noticed that the extract of the testis enhances the permeability of the animal tissues, and named it "spreading factor". Subsequently, the spreading factor was found to be identical with hyaluronidase ( $\mathrm{C} \mathrm{h}$ a in and $\mathrm{D} \mathrm{u}$ th i e, 1940).

Though the biochemical and biophysical researches had been elaborated, the morphological approach has not yet been tried since 1928. This paper deals with the demonstration of the localization of sheep hyaluronidase in the testis and in other urogenital organs, using fluorescent antibody method.

\section{Materials and methods}

$20 \mathrm{mg}$ of crystalline hyaluronidase* from sheep testis was dissolved in $1 \mathrm{ml}$ of cold $0.05 \mathrm{M}$ phosphate buffer, $\mathrm{pH}$ 7.4. The solution was then mixed with the equal volume of the complete Freund's adjuvant, emulsified well and injected subcutaneously in the foot pads as well as intramuscularly in the muscle of the shoulder of rabbits. For booster injection, $10 \mathrm{mg}$ of the enzyme dissolved in the phosphate buffer was administrated intravenously on the 36 th day from the initial injection, with the preliminary intravenous injection of restamin**. After a week from the booster injection, the blood was harvested from the carotid artery or by the heart puncture. The antibody titer was checked prior to the bleeding to see whether the titer was enough high or not.

The antisera from rabbits were pooled and the titer was examined again by passive hemagglutination method (Stavitsky, 1954). The

* Sigma Chemical Co., St. Louis, Mo.

** Kowa Chemical Co., Tokyo, Japan. 
aliquots were kept at $4^{\circ} \mathrm{C}$ and used for the gel-diffusion test and for the preparation of the fluorescent antibody solution, the rest of the aliquots were stored in the deep freezer at $-20^{\circ} \mathrm{C}$. The conjugation was carried out in the same manner as reported in the previous paper ( $\mathrm{Yasuda}$ and Coons, 1966). The value of $\mathrm{F} / \mathrm{P}$ molar ratio (M c Devitt et al., 1963) was 1.0. Three precipitin lines were obtained on the gel-diffusion plate, indicating at least three antigen-antibody systems were present. Further analysis of the antigen revealed the fact that there was no contamination of albumin or other serum proteins in the antigen. Moreover there was no common factor with bovine hyaluronidase in the material used as the antigen. After these close examinations about the purity of the antigen, it was decided to use the antibody prepared against this antigen, without absorption with the homogenate of the testis of other kind of animals or without further purification of the commercial hyaluronidase.

The testis, epididymis, ductus deferens and the prostate of the sheep were obtained in the slaughter house, being taken as quickly as possible after the sacrifice of the animal. The tissues were cut into small pieces of approximately $0.5 \times 0.5 \times 0.5 \mathrm{~cm}$ in size and quickly frozen in isopentane quenched in ethanol-dry ice mixture. The frozen tissues were kept in the deep freezer at $-20^{\circ} \mathrm{C}$, and were cut at $5 \mu$ by a rotary microtome in the cryostat kept at $-18^{\circ} \mathrm{C}$, as occasion demanded. The small blocks of the tissues were fixed with one of the fixatives mentioned later, dehydrated and embedded in paraffin. The frozen sections were quickly dried with the air stream at room temperature and fixed with the following variety of the fixatives for 30 minutes at room temperature; absolute acetone, 99\% ethanol, $10 \%$ ethanol in absolute acetone, $50 \%$ ethanol in absolute acetone, $10 \%$ formalin and $1 \%$ acetic acid in absolute ethanol. The copper sulfate was mixed in the fixatives as the inhibitor for enzyme activity at the final concentration of $10^{-4} \mathrm{~mol}$.

Controls were examined in the ways which were described by C o o n s $(1950,1956$, and 1958) C herry et al. (1960) and by Y a s u d a et al. (1963 and 1964).

\section{Result}

The antisera prepared against sheep hyaluronidase were titrated by the passive hemagglutination method. The endpoint of the titration was beyond 525,888 . This number proved that the titer of antisera is high enough to use as fluorescein-labelled antibody solution. 
Testis: The cells which line near the basement membrane of the seminiferous tubule, most likely the spermatogonia, and the interspace between them show strong fluorescence which gradually diminishes towards the center of the tubule. The specific fluorescence is often seen in the cytoplasm of the spermatogonia and the spermatocytes. Though it is weak, the fluorescence is also observed in the innermost layer where the spermatid or the sperms are crowded. The presence of the specific fluorescence in the Sertoli cell is actually obscure, because the outline of this cell is not distinct. Since the interstice among each spermatogonium is fairly wide and filled with the fluorescent substance under the fluorescence microscope, this space may correspond to the site of the Sertoli cells. The interspace between the seminiferous tubule is occupied by the connective tissue cells and with the interstitial cells. The interstitial cells, demonstrate strong fluorescence together with some connective tissue cells just around them.

Epididymis: The specific fluorescence is seen only in the place where the sperms are clustered.

Ductus deferens: The duct is examined precisely, being divided into three portions, namely the part near the testis, intermediate portion and the part close to the prostate. Any of above mentioned three portions did not show specific fluorescence.

Prostate: The presence of the antigen was not recognized in the prostate.

\section{Discussion}

After the report of Duran-Reynals (1928), C hain and and $D$ othie (1940) found the spreading factor as the identical substance to the hyaluronidase. M e y e r (1937) observed that the autodigested solution of the pneumococcus bacilli reacted on the hyaluronic acid to produce oligosaccharide, and named it hyaluronidase. According to $\mathrm{H}$ a se g a w a (1968), the hyaluronidase is present in the snake toxin, pneumococcus, streptococcus, staphylococcus as well as in the testis. He classified the enzyme in three types, namely hyaluronidase from testis, from snake toxin and from bacteria. Hyaluronidase, regardless of the type, is fairly unstable enzyme and is very difficult to purify, since it tends to loose its enzymatic activity in the aqueous solution. This might be the main reason why the antigen could not be further purified in this study.

The histological distribution of hyaluronidase revealed in this study was in the cytoplasm of spermatogenic cells, in the interspace between each spermatogonia, in the Sertoli cells and in the inter- 
stitial cells. Since there has been no other report on the localization of the hyaluronidase on the histological level, the result of this work can not be compared with others. But, hyaluronidase is reported to be present in the spermatocyte and also in the semen ( $\mathrm{S}$ w y e $\mathrm{r}, 1947$ ). According to $\mathrm{Kepp} \mathrm{(1954),} \mathrm{the} \mathrm{activity} \mathrm{of} \mathrm{hyaluronidase} \mathrm{in} \mathrm{the}$ semen has an intimate relationship with the concentration of the sperm, and the life of the sperm is prolonged by acid of the enzyme. In this study, the presence of the antigen in the sperm was not clearly demonstrated, possibly because sheep spermatocytes are too small to show the inner structure.

As far as the origin of the production of the enzyme is concerned, the interstitial cell or Sertoli cell might be the presumptive origin. Supposed hyaluronidase may be produced in the interstitial cell, the enzyme might be firstly diffused out into the connective tissue around the interstitial cell, and may reach the basement membrane of the seminiferous tubule. Later, the enzyme may be taken into the spermatogonia, also into the interspace among the spermatogonia and moreover into Sertoli cell. It is not clear whether or not the enzyme found at the center of the seminiferous tubule is transferred through the spermatogonia, spermatid, spermatocyte and is carried into the sperm or comes through the interspace between each spermatogenic cell towards the center of the tubule. At least, some of the spermatogonia are proved to contain hyaluronidase.

Judging from the immunological examinations, the antigen used in this study was not pure enough, though it was highly purified from the biochemical point of view. Therefore, the immunofluorescein points out the place where some of the components of hyaluronidase is localized, but not exactly the correct localization of pure hyaluronidase.

\section{Conclusion}

The localization of hyaluronidase in the sheep urogenital organs was examined by use of immunofluorescence method.

The enzyme was localized in the seminiferous tubule, specifically in the layer which was close to the basement membrane. The concentration of the enzyme lowered toward the center of the seminiferous tubule. The enzyme might possibly be in the spermatogonium as well as in Sertoli cell which occupies the interspace between each spermatogenic cell. The interstitial cell also contains hyaluronidase and is supposed to be one of the origins of the production of the enzyme. The Sertoli cells may possibly supply the enzyme. 
In the epididymis, the enzyme was found only at the place where the cluster of the sperm was recognized. Hyaluronidase was not noticed either in the ductus deferens or in the prostate.

\section{References}

Akabori, Sh.: Handbook of the enzyme. ed. by Sh. Akabori, Asakura Book Co., Tokyo, pp. 486-487, 1966.

$\mathrm{Ch}$ a in, E. and E.S. D u t h i e: Identity of hyaluronidase and spreading factor. Brit. J. Exp. Pathol., $21: 324-333,1940$.

Coons, A.H. and M.H. Kaplan: Localization of antigen in tissue cells. II. Improvement in a method for detection of antigen by means of fluorescent antibody. J. Exp. Med., $91: 1-13,1950$.

- : Histochemistry with labeled antibody. Intern Rev. Cytol., ed. by G.H. B ourne and J.F. Dan ie 11 i, Acad. Press, New York, 5: 1-23, 1956.

- : Fluorescent antibody methods. General Cytochemical Methods, ed. by J.F. D a n i 11 i, Acad. Press, New York, $1: 339-422,1958$.

Cherry, W.B., M. Gold $\mathrm{man}$ and Th. R. Carski: Fluorescent antibody techniques in the diagnosis of communicable disease. U.S. Goverment Printing Office, Washington, D.C., 1960.

Duran-Reynals, F.: Exaltation de Lactivite du virus vaccinal par les extraits de certains organes. Société de Biologie, $99: 6-7,1928$.

Haseg a wa, E., S. Suzuki, N. Seno and Sh. Hirano: Structure and function of polysaccharide. Kagaku-no-Ryoiki, Nankodo, Tokyo, Supplement 83 : 135-151, 1968. (in Japanese)

Ke p p, R.K. und H.W. Vasterling: Zur Frage der praktischen Bedeutung der Sperma hyaluronidase. Dtsch. Med. Wschr. 79:278, 1954.

Marsha11, J.D., W.C. Evel and C.W. Smith: Superiority of fluorescein isothiocyanate (Riggs) for fluorescent-antibody technic with a modification of its application. Proc. Soc. Exp. Biol. Med., 98: 898-900, 1958.

Mc Devit t, H. O., J.H. Peters, L.W. Pollard, J.G. Harter and A.H. Coons: Purification and analysis of fluorescein-labeled antisera by column chromatography. J. Immunol., $90: 634-642,1963$.

Meyer, K., R. Dubos and E.M. Smith: The hydrolysis of the polysaccharide acids of vitreous humor, of umbilical cord, and of streptococcus by the autolytic enzyme of pneumococcus. J. Biol. Chem. $118: 71-78,1937$.

Rossi, G.B., E. Caccavale and L.C. Porrazzi: Salicylate and increased vascular permeability due to hyaluronidase. Nature, $200: 685-686,1963$.

Sorn, E. and F. I on escu-Stolan: The purification of testicular hyaluronidase by chromatography on a mixed column. J. Chromatography, $17: 338-341,1965$.

Stavitsky, A. B. : Micromethod for the study of proteins and antibodies. 1. Procedure and general application of hemaggultination and hemaggultination-inhibition reactions with tannic acid and protein treated red blood cells. J. Immunol., 72 : 360-368, 1954.

Swyer, G.I.M.: The hyaluronidase content of semen. Biochem. J., $41: 409-417$, 1947.

Y a suda, K., S. Toyoshima and T. Aki y a ma: Fluorescent antibody methods (III), Modern Media, $9: 332-347,1963$. (in Japanese)

Yasuda, K., T. Suzuki, S. Toy os hima and T. Aki y a ma: Fluorescent antibody methods (V). Modern Media, 10:506-512, 1964. (in Japanese) 


\section{Explanation of figures}

Fig. 1. The gel diffusion test on the agar plate. Three precipitin lines are recognized on the lower left corner.

Fig. 2. The testis of the sheep, stained with FITC-labelled antihyaluronidase globulin. The interstitial cells show strong fluorescence. The specific fluorescence is also noticed in the basal part of the seminiferous tubule. The fluorescence diminishes toward the center of the tubule. The nuclei of the cells in the seminiferous tubule are negative of the enzyme. $\times 200$

Fig. 3. This picture illustrates the basal part of the seminiferous tubule. The spermatogonia, spermatocytes and the Sertoli cells contain the enzyme. The inner layer demonstrates weaker reaction than the outer layer. The specific fluorescence is also seen diffusely in the interstitial connective tissue. $\times 400$

Fig. 4. The histological feature is similar to Fig. $3 . \times 600$ 
Plate
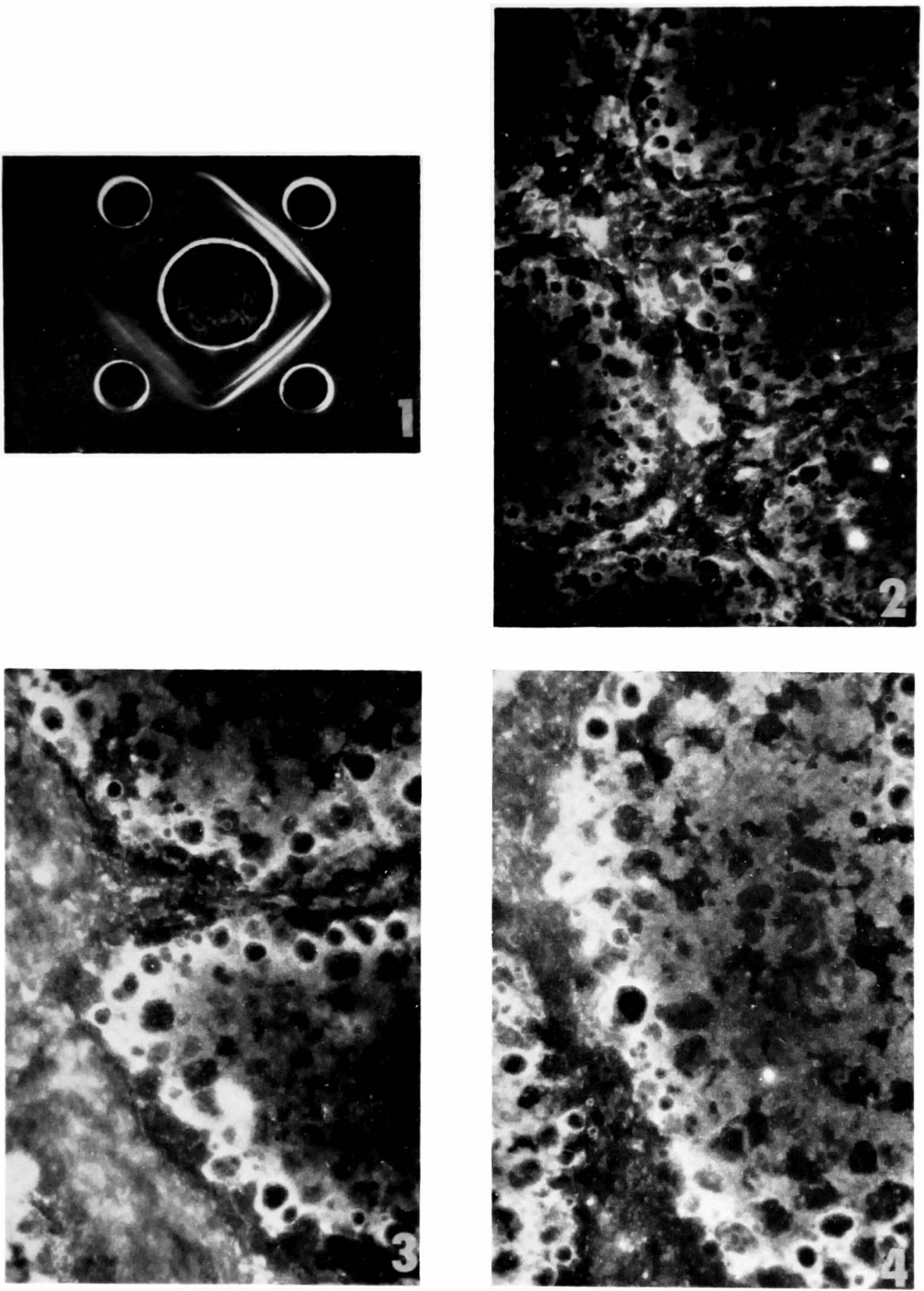

Nagakubo, K. Takano and K. Yasuda 